\title{
Pengaruh Kalium Permanganat dan Berbagai Massa Arang Kayu Terhadap Mutu Buah Jambu Bij 'Crystal' (Psidium Guajava L.) Selama Penyimpanan
}

The Effect of Permanganate Potassium and Various Mass of Wood Charcoal on Quality of 'Crystal' Guava Fruit (psidium guajava I.) During Storage

\author{
Yurica Desmonda ${ }^{1)}$, Dwi Dian Novita ${ }^{2)}$, Budianto Lanya ${ }^{3)}$ \\ ${ }^{1)}$ Alumni Jurusan Teknik Pertanian, Fakultas Pertanian, Universitas Lampung \\ ${ }^{2)}$ Staf Pengajar Jurusan Teknik Pertanian, Fakultas Pertanian, Universitas Lampung \\ Jl. Sumantri Brodjonegoro No. 1, Gedongmeneng, Bandar Lampung 35145 Provinsi Lampung \\ Email : yuricadesmonda@gmail.com
}

\begin{abstract}
ABSTRAK
Salah satu cara memperlambat proses pematangan jambu biji (Psidium guajava L.) adalah dilakukan pengoksidasian etilen dengan menggunakan kalium permanganat (KMnO4) dan arang kayu sawo sebagai bahan pembawanya. Tujuan penelitian ini adalah mengetahui massa campuran arang dan $\mathrm{KMnO} 4$ terbaik selama penyimpanan pada suhu ruang $\left(26^{\circ}-30^{\circ} \mathrm{C}\right)$ dan suhu rendah $\left(10^{\circ}-12^{\circ} \mathrm{C}\right)$, mengamati perubahan fisik dan kimia buah jambu biji 'crystal', dan mengetahui umur simpan buah jambu biji 'crystal'. Penelitian ini menggunakan Rancangan Acak Lengkap 5 perlakuan pada suhu ruang dan suhu rendah yaitu campuran $2 \mathrm{~g}$ arang dan $\mathrm{KMnO} 4,4 \mathrm{~g}$ arang dan $\mathrm{KMnO} 4,6 \mathrm{~g}$ arang dan $\mathrm{KMnO} 4,8 \mathrm{~g}$ arang dan $\mathrm{KMnO}$, 10g arang dan $\mathrm{KMnO}$. Hasil penelitian menunjukkan bahwa penggunaan $\mathrm{KMnO} 4$ sebagai pengoksidasi etilen mampu memperlambat penurunan kekerasan, dan peningkatan kandungan padatan terlarut. Perlakuan terbaik penyimpanan suhu ruang adalah Ta1 ( $2 \mathrm{~g}$ arang+ KMnO4) dan Tc1 (2g arang+ KMnO4) pada suhu rendah. Hasil analisis statistik pada $\alpha=5 \%$ pada penyimpanan suhu ruang menunjukkan perlakuan berpengaruh nyata terhadap parameter kandungan padatan terlarut, sedangkan pada suhu rendah perlakuan berpengaruh nyata terhadap parameter kekerasan dan kandungan padatan terlarut.
\end{abstract}

Kata kunci :arang kayu, etilen, jambu biji 'crystal', larutan KMnO4.

\section{ABSTRACT}

One of the ways to slow down the maturation process of GUAVA FRUIT (Psidium guajava L.) is by oxidizing ethylene using permanganate potassium (KMnO4) and sapodilla wood charcoal as the material of carrier. The aims of this research are to find the best mixture of charcoal mass and $\mathrm{KMnO} 4$ during the storage at room $\left(26^{\circ}-30^{\circ} \mathrm{C}\right)$ and low temperature $\left(10^{\circ}-12^{\circ} \mathrm{C}\right)$, to observe the physical and chemical changes of crystal guava fruit and to find out the shelf life of crystal guava fruit during the storage. This research used random complete design with 5 treatment in each temperature, namely $2 \mathrm{~g}$ charcoal and $\mathrm{KMnO} 4,4 \mathrm{~g}$ charcoal and $\mathrm{KMnO}, 6 \mathrm{~g}$ charcoal and $\mathrm{KMnO} 4,8 \mathrm{~g}$ charcoal and $\mathrm{KMnO} 4,10 \mathrm{~g}$ charcoal and KMnO4. The result showed that the use of KMnO4 as the Oxidize of ethylene was able to slow the violence decline and the increase of dissolved solids content. The best treatment of room temperature storage was Ta1 (2g charcoal + KMnO4) and Tc1 (2g charcoal + KMnO4) at low temperature storage. Results of statistical analysis at $\alpha=5 \%$ of storage at room temperature showed the treatment significantly affected the parameters of dissolved solids content, while at low temperature the treatment significantly affected parameters of hardness and dissolved solids content .

Keyword : charcoal, ethylene, crystal guava, KMnO4 solution

Diterima : 28 Agustus 2016; Disetujui : 10 Oktober 2016; Publish Online : 07 Maret 2017 


\section{PENDAHULUAN}

Jambu biji (Psidium guajava L.) 'crystal' merupakan buah yang memiliki daging buah tebal, berbiji sedikit, dan memiliki rasa yang lembut dan renyah sehingga menjadi salah satu buah jambu biji yang memiliki nilai ekonomi yang tinggi. Jambu biji 'crystal', sebagaimana buah jambu biji pada umumnya, tergolong buah klimaterik yang mengalami perubahan pola respirasi yang mendadak sebelum terjadinya proses kelayuan (Winarno dan Aman 1981).

Laju respirasi merupakan petunjuk yang baik untuk daya simpan buah yang sudah dipanen. Menurut Pantastico (1989), ada dua faktor yang dapat mempengaruhi respirasi yaitu faktor internal dan faktor eksternal. Salah satu faktor internal yaitu etilen, menurut Winarno dan Aman (1981) etilen adalah senyawa hidrokarbon tidak jenuh yang pada suhu kamar berbentuk gas. Menurut sholihati (2004), secara umum perlakuan bahan penyerap etilen kalium permanganat memberikan pengaruh terhadap penghambatan pematangan dengan ditekannya produksi etilen dan dapat dipertahankannya warna hijau, tekstur serta aroma pisang raja selama 15 hari.

Kontak langsung antara $\mathrm{KMnO}_{4}$ dengan produk pertanian tidak dianjurkan karena sifat $\mathrm{KMnO}_{4}$ yang beracun (Coles, et al., 2003), diperlukan bahan penyerap $\mathrm{KMnO}_{4}$ agar dapat digunakan sebagai pengoksidasi etilen, sehingga dalam penelitian ini menggunakan $\mathrm{KMnO}_{4}$ dengan bahan penyerap yaitu arang kayu sawo.

Tujuan dari penelitian ini adalah untuk mengetahui arang+ $\mathrm{KMnO}_{4}$ terbaik selama penyimpanan pada suhu ruang dan suhu rendah, mengetahui perubahan fisik dan kimia buah jambu biji 'crystal' selama penyimpanan dan mengetahui umur simpan buah jambu biji 'crystal'.

\section{BAHAN DAN METODE}

Penelitian ini dilaksanakan pada bulan Juni hingga Juli 2015 di Laboratorium Rekayasa Bioproses dan Pascapanen Jurusan Teknik Pertanian Universitas Lampung.

\section{Alat dan Bahan}

Alat yang digunakan adalah gelas ukur, show case, timbangan analitik OHAUS, refraktometer, rheometer dan alat gelas lainnya. Bahan yang digunakan adalah buah jambu biji 'crystal', $\mathrm{KMnO}_{4}$ $4 \%(\mathrm{~b} / \mathrm{v})$, arang kayu sawo, plastik polietilen densitas rendah dengan ketebalan $0,1 \mathrm{~mm}$, dan kotak karton $12 \times 12 \times 6,5 \mathrm{~cm}$. Bahan untuk analisis yaitu akuades, amilum, dan lod 0,01N.

\section{Metode}

Penelitian ini dimulai dengan mengukur akuades sebanyak $500 \mathrm{ml}$ dan timbang serbuk KMnO4 sebanyak $20 \mathrm{~g}$, campurkan sedikit demi sedikit serbuk $\mathrm{KMnO} 4$ ke dalam akuades sampai jenuh. Aduk larutan sampai merata dan kemudian disimpan dalam ruang kedap cahaya selama 1 malam, setelah itu larutan siap digunakan. Kemudian mengukur arang kelipatan 2 gram setiap perlakuan. Menyelupkan arang selama 10 menit ke dalam larutan $\mathrm{KMnO} 4$ yang telah dibuat, kemudian arang ditiriskan selama 5 menit setelah itu dimasukkan ke dalam kantung kain.

Buah jambu biji 'crystal' yang telah dipilih, dicuci dahulu kemudian dikeringkan. Penyimpanan dilakukan pada suhu yang berbeda yaitu:

$\mathrm{Ta}=$ suhu ruang $\left(28-30^{\circ} \mathrm{C}\right)$

$\mathrm{Tc}=$ suhu rendah $\left(10-12^{\circ} \mathrm{C}\right)$

Perlakuan yang digunakan adalah terdiri dari 5 level massa arang $+\mathrm{KMnO}_{4}$, dianalisis pada masing-masing suhu penyimpanan untuk perlakuan suhu ruang yaitu:

$\mathrm{Ta} 1=2$ gram Massa arang+KMnO4

$\mathrm{Ta} 2=4$ gram Massa arang $+\mathrm{KMnO} 4$

$\mathrm{Ta} 3=6$ gram Massa arang+KMnO4

$\mathrm{Ta} 4=8$ gram Massa arang+KMnO4 8 gram

$\mathrm{Ta} 5=10$ gram Massa arang+KMnO4 10 gram

Perlakuan yang digunakan 5 level massa arang+ $\mathrm{KMnO}_{4}$ dianalisis pada masing-masing suhu penyimpanan untuk perlakuan suhu rendah yaitu:

$\mathrm{Tc1}=2$ gram Massa arang+KMnO4
$\mathrm{Tc} 2=4$ gram Massa arang+KMnO4
$\mathrm{Tc} 3=$ Massa arang+KMnO4 6 gram
$\mathrm{Tc} 4=$ Massa arang+KMnO4 8 gram
$\mathrm{Tc5}=$ Massa arang+KMnO4 10 gram

Buah jambu biji 'crystal' dimasukkan ke dalam kotak karton $12 \times 12 \times 6,5 \mathrm{~cm}$, tiap kotak berisi 3 buah, kemudian diberi arang yang telah menyerap $\mathrm{KMnO}_{4}$. Setelah itu ditutup plastik polietilen dan disimpan. Pengamatan dilakukan

28 Pengaruh Kalium Permanganat dan Berbagai Massa Arang Kayu Terhadap Mutu Buah Jambu Biji 'Crystal' (Psidium Guajava L.) Selama Penyimpanan 
dua hari sekali pada penyimpanan suhu ruang dan empat hari sekali pada suhu rendah. Parameter yang diukur adalah penyusutan bobot buah, kekerasan buah, kandungan padatan terlarut (KPT), dan uji kadar vitamin C. Analisis data menggunakan rancangan acak lengkap (RAL), apabila terdapat perbedaan hasil uji maka dilanjutkan dengan uji BNT taraf $5 \%$.

\section{HASIL DAN PEMBAHASAN}

\section{Susut Bobot}

Pengukuran dilakukan dua hari sekali pada penyimpanan suhu ruang selama 18 hari, sedangkan pada penyimpanan suhu rendah dilakukan empat hari sekali selama 36 hari. Peningkatan susut bobot diupayakan dapat ditekan dengan bahan penyerap etilen dengan batas hari penyimpanan $0 \leq X \leq 18$. Grafik susut bobot dapat dilihat pada Gambar 1, nilai kontrol dan perlakuan hari ke-2 mencapai 3,5\% hingga hari ke-18 mencapai $28,3 \%$. Laju peningkatan susut bobot sebesar 1,622\% per hari. Menurut (Usman, 2013) pada buah yang mengalami kehilangan air berlebihan (5 - 10\%) dari bobot awal akan menyebabkan susut jumlah dan susut kualitas pada produk. Pada penyimpanan batas normal susut bobot $5-10 \%$ sampai hari ke-6, dan masih dilanjutkan penyimpanan selama 18 hari hingga memiliki susut bobot 28,3\%. Hal ini disebabkan karena buah masih dalam keadaan layak konsumsi. Hasil analisa sidik ragam $(\alpha=0,05)$ perlakuan tidak berpengaruh nyata.

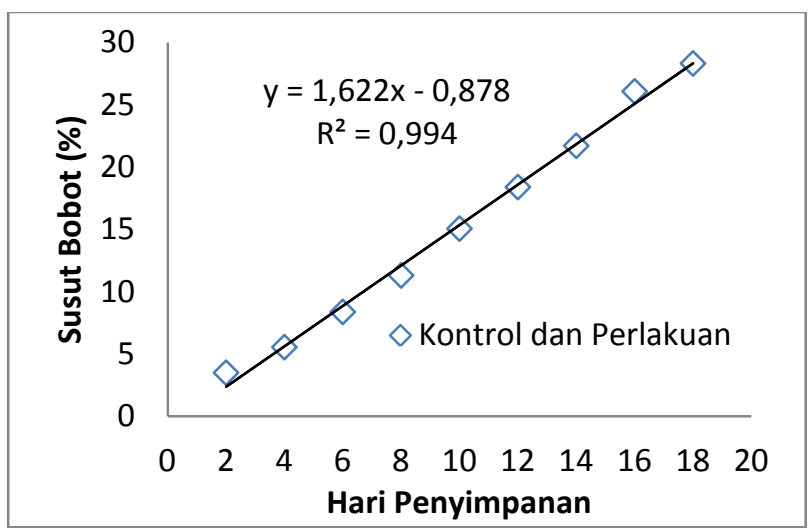

Gambar 1. Grafik pengaruh perlakuan terhadap susut bobot buah jambu biji 'crystal' pada suhu ruang selama penyimpanan
Hasil pengamatan susut bobot selama penyimpanan suhu rendah dengan batasan hari penyimpanan $0 \leq X \leq 36$ dapat dilihat pada Gambar 2 grafik susut bobot penyimpanan pada suhu rendah, nilai susut bobot kontrol dan perlakuan hari ke-2 mencapai 2,8\% hingga hari ke-36 mencapai 32,2\%, sama halnya dengan penyimpanan pada suhu ruang batas susut bobot melebihi 5 - 10\% karena buah pada penyimpanan suhu rendah selama 36 hari masih layak konsumsi. Laju peningkatan susut bobot penyimpanan suhu rendah mencapai 0,924\%. Penyimpanan pada suhu rendah mampu lebih mempertahankan penyusutan bobot buah dibandingkan dengan buah yang disimpan pada suhu ruang. Menurut (Santoso ,2006) penyimpanan suhu rendah dapat memperpanjang masa hidup jaringan-jaringan dalam bahan pangan tersebut karena aktivitas respirasi menurun. Hasil analisa sidik ragam susut bobot perlakuan tidak berpengaruh selama penyimpanan suhu rendah.

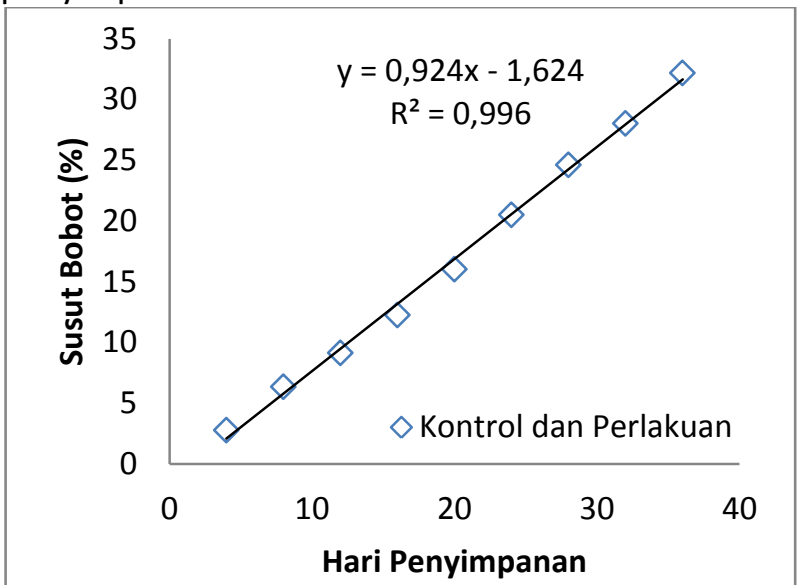

Gambar 2. Grafik pengaruh perlakuan terhadap susut bobot buah jambu biji 'crystal' pada suhu rendah selama penyimpanan

\section{Kekerasan}

Pengukuran kekerasan dilakukan menggunakan rheometer dengan batasan hari penyimpanan $0 \leq X \leq 18$, menunjukkan bahwa pada masing-masing perlakuan terlihat angka yang semakin rendah yang menunjukkan terjadi penurunan kekerasan atau melunaknya buah dengan bertambahnya umur simpan. Gambar 3 menunjukkan tingkat kekerasan buah jambu biji 
'crystal' pada penyimpanan suhu ruang, nilai kekerasan kontrol dan perlakuan hari ke-2 mencapai 3,3N dan mengalami penurunan hingga hari ke-18 penyimpanan mencapai $1,8 \mathrm{~N}$. Laju penurunan kekerasan sebebesar $-0,084 \mathrm{~N}$ per hari. Menurut (Rahmanto, 2005) menyatakan bahwa proses pematangan buah terjadi dengan cepat sehingga proses perubahan kekerasan buah terjadi dengan cepat pula. Sebaliknya, pada buah yang diberi perlakuan terjadi proses penyerapan etilen oleh arang kayu yang mengandung $\mathrm{KMnO}_{4}$. Menurut Dumadi (2001), saat perubahan tekstur buah menjadi lunak dan diikuti oleh kadar pati yang menurun. Hasil analisa sidik ragam kekerasan perlakuan tidak berpengaruh selama penyimpanan suhu rendah.

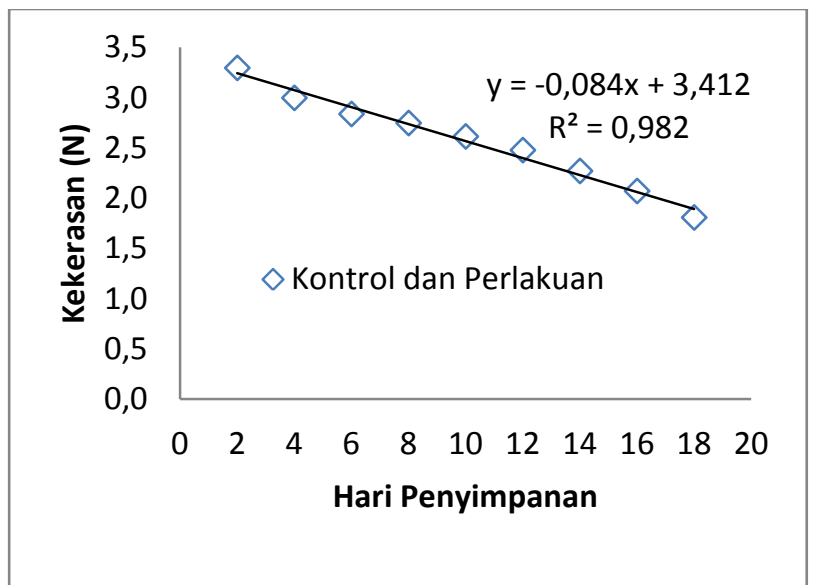

Gambar 3. Grafik pengaruh perlakuan terhadap kekerasan buah jambu biji 'crystal' selama penyimpanan pada suhu ruang

Pada suhu rendah selama penyimpanan tingkat kekerasan buah jambu biji 'crystal' mengalami penurunan dengan batasan hari penyimpanan $0 \leq X \leq 18$. Gambar 4 grafik kontrol selalu mengalami penurunan lebih cepat tingkat kekerasan dibandingkan dengan perlakuan dan menunjukkan laju penurunan tingkat kekerasan pada kontrol sebesar $-0,049 \mathrm{~N}$, sedangkan untuk perlakuan Tc1 hanya mengalami laju penurunan sebesar $-0,028 \mathrm{~N}$. nilai tingkat kekerasan kontrol pada hari ke-4 penyimpanan mencapai 3,28 N. Sedangkan untuk perlakuan Tc1 mencapai 3,00 N. Hingga akhir penyimpanan hari ke-36 nilai tingkat kekerasan kontrol menurun menjadi 1,53 $\mathrm{N}$ dan untuk perlakuan Tc1 mampu mempertahankan tingkat kekerasan buah 2,12 N.

Hasil analisa sidik ragam menunjukkan bahwa massa arang berpengaruh nyata hanya pada hari penyimpanan ke-32, dimana Tc1 berbeda nyata dengan kontrol, perlakuan Tc3, dan perlakuan Tc5 kecuali dengan Tc2 dan Tc4.

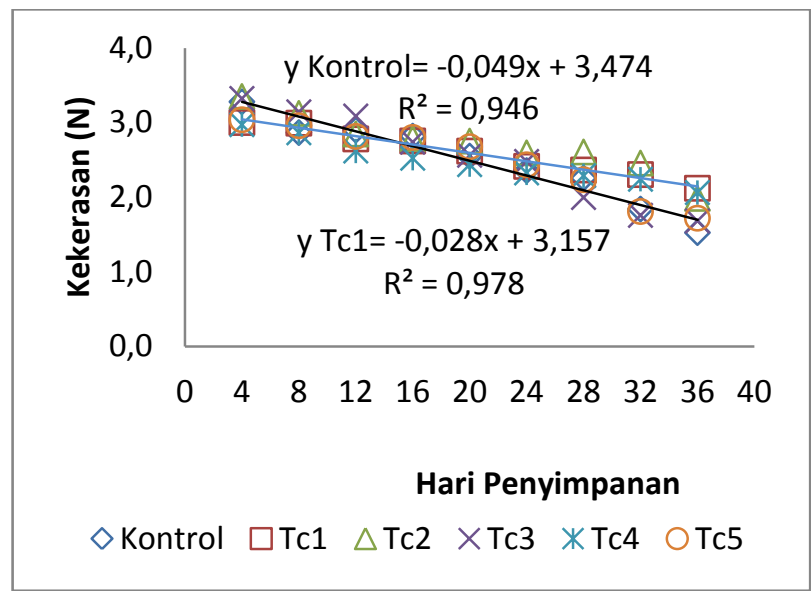

Gambar 4. Grafik pengaruh perlakuan terhadap kekerasan buah jambu biji 'crystal' selama penyimpanan pada suhu rendah.

\section{Kandungan Padatan Terlarut (KPT)}

Berdasarkan hasil nilai kandungan padatan terlarut selama penyimpanan pada suhu ruang dengan batas hari penyimpanan $0 \leq X \leq 18$ kontrol mengalami peningkatan KPT pada hari penyimpanan ke-12 mencapai $10,04^{\circ} \mathrm{Brix}$ hingga akhir penyimpanan ke-18 meningkat menjadi $11,99^{\circ}$ Brix. Perlakuan yang memiliki nilai KPT terendah dibandingkan dengan perlakuan lain maupun kontrol pada penyimpanan suhu ruang yaitu pada perlakuan Ta1 $9,50^{\circ} \mathrm{Brix}$, dan perlakuan Ta3 $9,44^{\circ}$ Brix, perlakuan yang memiliki nilai KPT tertinggi terdapat pada Ta2 mencapai $9,90^{\circ}$ Brix. Berdasarkan Gambar 5 dapat dilihat grafik peningkatan KPT tanpa diberi perlakuan atau kontrol mengalami peningkatan lebih tinggi mencapai $0,223^{\circ} \mathrm{Brix}$ per hari sedangkan jambu biji 'crystal' yang diberi perlakuan Ta1 hanya mencapai $0,187^{\circ}$ Brix. Kenaikan nilai KPT pada jambu biji disebabkan oleh hidrolisis karbohidrat menjadi senyawa glukosa dan fruktosa. Selain itu kenaikan nilai KPT disebabkan oleh degradasi komponen dinding sel seperti pektin, selulosa, hemiselulosa 
dan lignin menjadi komponen yang lebih sederhana yang dapat larut dalam air (Sunarmani et al, 1996). (Fransiska, 2013) glukosa yang terbentuk dalam buah akan dipakai untuk proses respirasi sehingga produksi glukosa di dalam jaringan buah juga mempengaruhi laju respirasi.

Hasil analisa sidik ragam untuk parameter KPT menunjukkan bahwa massa arang berpengaruh nyata pada hari ke-2 dan hari ke-4. Hasil uji lanjut BNT pada penyimpanan hari ke-2 yaitu Ta1 berbeda nyata pada seluruh perlakuan kecuali dengan Ta4, sedangkan penyimpanan ke-4 Ta1 berpengaruh nyata dengan seluruh perlakuan kecuali dengan perlakuan Ta5.

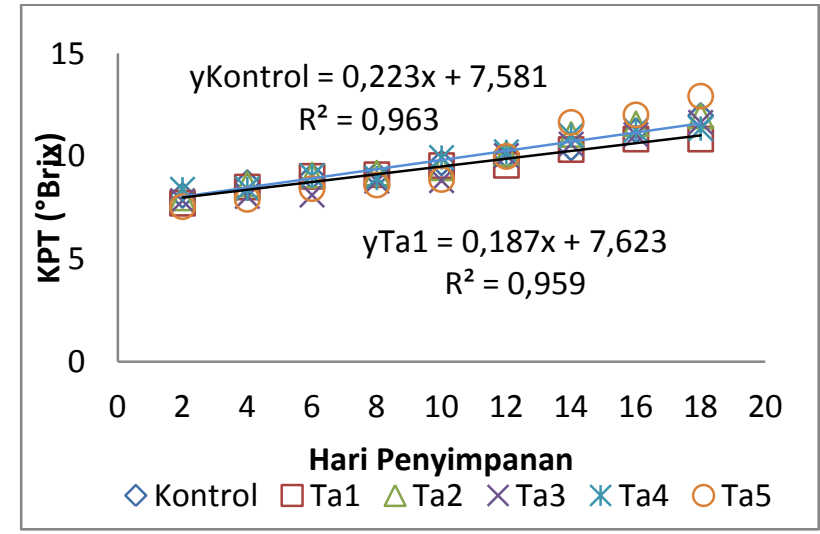

Gambar 5. Grafik kandungan padatan terlarut pada buah jambu biji 'crystal' selama penyimpanan pada suhu ruang

Nilai kandungan padatan terlarut mengalami peningkatan laju kontrol lebih tinggi mencapai $0,166^{\circ} \mathrm{Brix}$, sebaliknya dibandingkan dengan perlakuan Tc1 yang hanya mencapai $0,115^{\circ} \mathrm{Brix}$ ( Gambar 6). Pada perlakuan Tc2 memiliki nilai terendah $9,15^{\circ}$ Brix dibandingkan dengan perlakuan lain. Kandungan padatan terlarut pada penyimpanan suhu rendah memiliki nilai lebih kecil dengan batas hari penyimpanan $0 \leq X \leq 36$ dibanding suhu ruang. Perhitungan kandungan padatan terlarut baik pada penyimpanan suhu ruang maupun suhu rendah menunjukkan semua perlakuan $\mathrm{KMnO}_{4}$ mampu menekan perubahan kandungan padatan terlarut.

Hasil analisa sidik ragam menunjukkan adanya pengaruh nyata pada perbedaan suhu dan massa arang pada hari ke-2, ke-16, ke-20, dan ke-
24, hasil uji lanjut Tc1 berbeda nyata dengan perlakuan Tc2 dan Tc3, dan tidak berbeda nyata pada control, Tc4 dan Tc5.

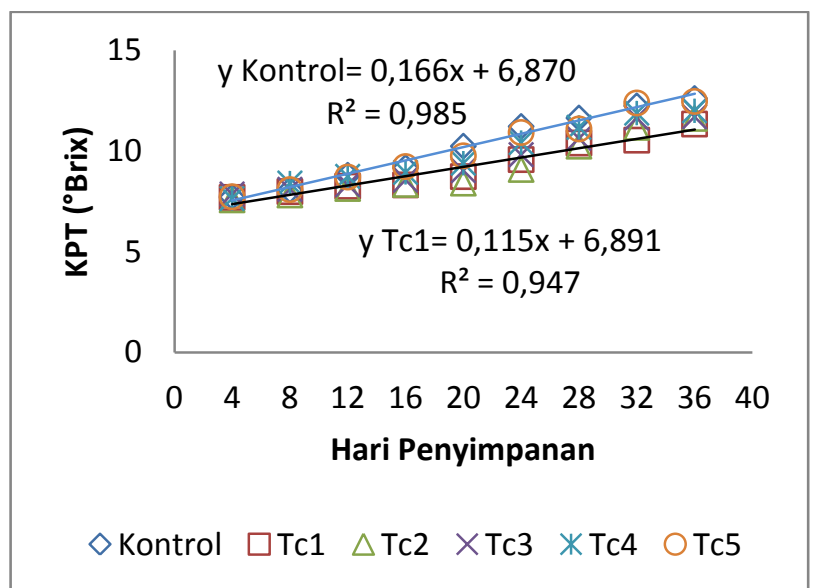

Gambar 6. Grafik kandungan padatan terlarut pada buah jambu biji 'crystal' selama penyimpanan pada suhu rendah

\section{Uji Kadar Vitamin C}

Hasil analisa vitamin C pada buah jambu biji 'crystal' di suhu ruang dengan batasan hari penyimpanan $0 \leq X \leq 18$ dapat dilihat pada Gambar 7 menunjukkan grafik peningkatan kadar vitamin $\mathrm{C}$ kontrol dan perlakuan hari ke-2 mencapai $32,8 \mathrm{mg} / 100 \mathrm{gr}$ hingga hari ke-18 mencapai $47,4 \mathrm{mg} / 100 \mathrm{~g}$. Laju peningkatan kadar vitamin C sebesar $0,896 \mathrm{mg} / 100 \mathrm{~g}$ per hari. Umur simpan buah jambu biji 'crystal' semakin lama menyebabkan meningkatnya kadar vitamin $\mathrm{C}$ yang terus menerus, sehingga pada perlakuan mampu mempertahankan kadar vitamin C dibandingkan dengan kontrol yang memiliki nilai lebih tinggi karena proses ripening buah lebih cepat. Purwantiningsih, dkk (2012), dalam penelitiannya tentang pengaruh umur petik $95-115$ hari selama sembilan hari penyimpanan terhadap kandungan vitamin C pada buah anggur menyatakan pemanenan buah saat muda mampu mempertahankan daya simpan buah sehingga dapat meningkatkan kandungan vitamin C. Hasil analisa sidik ragam kadar vitamin C selama penyimpanan suhu ruang dan hasil yang diperoleh perlakuan tidak berpengaruh. 


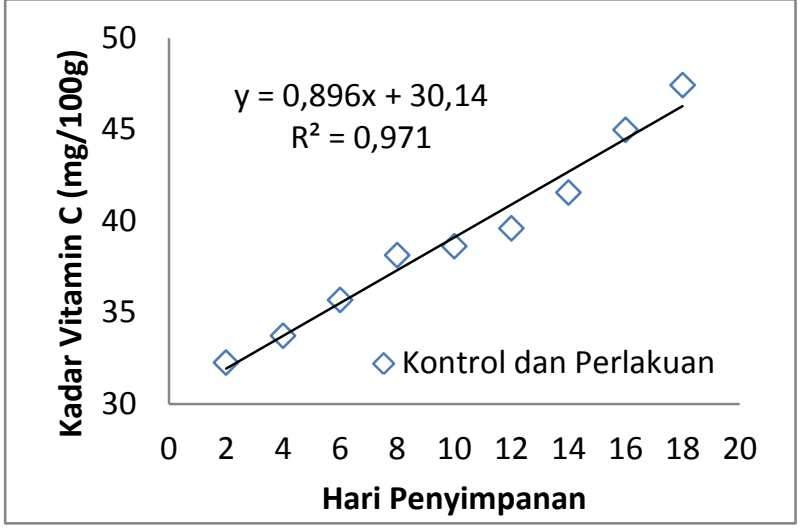

Gambar 7. Grafik kadar vitamin C buah jambu biji 'crystal' selama penyimpanan pada suhu ruang

Pada analisa kadar vitamin C selama penyimpanan suhu rendah dengan batas hari penyimpanan $0 \leq X \leq 36$ grafik dapat dilihat pada Gambar 8, peningkatan nilai vitamin $C$ penyimpanan hari ke-2 kontrol dan perlakuan mencapai 32,8mg/100g hingga hari ke-36 penyimpanan mencapai $47,4 \mathrm{mg} / 100 \mathrm{~g}$. Laju peningkatan kadar vitamin C sebesar $0,44 \mathrm{mg} / 100 \mathrm{~g}$ per hari. Trenggono dan sutaji, 1989 dalam Rachmawati, 2009 yang menyatakan bahwa tujuan penyimpanan suhu rendah $\left(10^{\circ}\right)$ adalah untuk mencegah terjadinya kerusakan tanpa mengakibatkan perubahan yang tidak diinginkan seperti terjadi pembusukan.

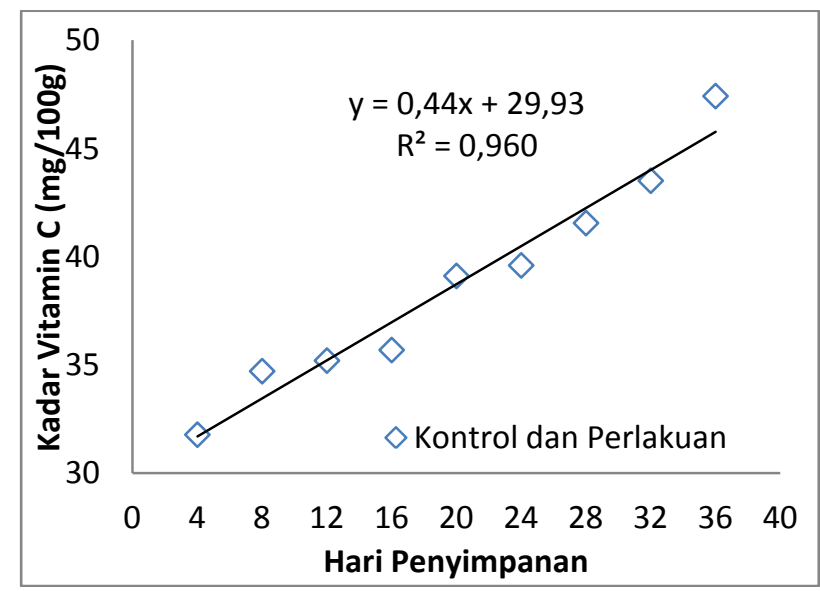

Gambar 8. Grafik kadar vitamin C buah jambu biji 'crystal' selama penyimpanan pada suhu rendah.

Analisis sidik ragam kadar vitamin C pada penyimpanan suhu rendah menunjukkan hasil perlakuan tidak berpengaruh tetapi cenderung mengalami peningkatan.

\section{KESIMPULAN DAN SARAN}

\section{Kesimpulan}

Berdasarkan hasil penelitian dan pembahasan maka dapat disimpulkan sebagai berikut:

1. Penggunaan perlakuan jumlah $\mathrm{KMnO}_{4}$ pada media arang sebagai pengoksidasi etilen mampu menekan penurunan kekerasan, dan peningkatan kandungan padatan terlarut.

2. Perlakuan terbaik penyimpanan suhu ruang adalah Ta1 (2 g arang+KMnO${ }_{4}$ ). Pada akhir penyimpanan (hari ke-18) memiliki nilai susut bobot 25,34\%, kekerasan 2,24N, kandungan padatan terlarut $10,84^{\circ}$ Brix dan untuk kadar vitamin C $44 \mathrm{mg} / 100 \mathrm{~g}$.

3. Perlakuan terbaik penyimpanan suhu rendah adalah Tc1 (2 g arang+KMnO 4 ). Pada akhir penyimpanan (hari ke-36) buah memiliki nilai susut bobot 28,02\%, kekerasan 2,12N, kandungan padatan terlarut $11,34^{\circ}$ Brix dan untuk kadar vitamin C $38,13 \mathrm{mg} / 100 \mathrm{~g}$.

4. Hasil analisis statistik pada $\alpha=5 \%$ pada penyimpanan suhu ruang, perlakuan berpengaruh nyata terhadap parameter kandungan padatan terlarut, sedangkan pada suhu rendah perlakuan berpengaruh nyata terhadap parameter kekerasan dan kandungan padatan terlarut.

\section{Saran}

Saran dari penelitian ini yaitu perlunya penelitian lanjutan dengan menggunakan massa arang 1 gram 2 gram dan 3 gram sebagai bahan penyerap $\mathrm{KMnO}_{4}$ dengan komoditas buah yang sama.

\section{DAFTAR PUSTAKA}

Coles, R, D. McDowell, and M.J. Kirwan. 2003. Food Packaging Technology. Blackwell Publishing. Denmark.

Dumadi, S.R. 2001. Penggunaan Kombinasi Adsorban untuk Memperpanjang Umur Simpan Pisang Cavendish. Jurnal teknik dan industri pangan. Vol XII, No. $1: 13-20$. 
Fransiska, A. 2013. Karakteristik Fisiologi Manggis (Garcinia mangostana L.) dalam Penyimpanan Atmosfer Termodifikasi. Jurnal Teknik Pertanian Lampung - Vol. 2, No 1. Feb-Mei:1-6.

Pantastico, ERB. 1989. Fisiologi Pasca Panen, Penanganan dan Pemanfaatan Buah-buahan dan Sayur-sayuran Tropika dan Subtropika. Penerjemah : Prof. Ir. Kamariyani dan Tjitrosoepomo. Gadjah Mada University Press. Yogyakarta.

Purwantiningsih, B. A.S. Leksono, dan B. Yanuwiadi. 2012. Pengaruh Umur Petik Dan Lama Penyimpanan Terhadap Kandungan Vitamin C Pada Buah Anggur (Vitis Vinifera L.). Jurnal El-Hayah Vol. 2, No. 2:64-69.

Rachmawati, R. 2009. Pengaruh Suhu dan Lama Penyimpanan Terhadap Kandungan Vitamin C Pada Cabai Rawit Putih (Capsicum frustescens). Jurnal Program studi Biologi Fakultas MIPA. XIII (2) : 36-40.

Rahmanto, D. 2005. Uji Penghambatan Kematangan Buah Alpukat Pada Penyimpanan Suhu Ruang Menggunakan $\mathrm{KMnO}_{4}$ dengan Absorben Arang Kayu dan
Pengemas Plastik Polietilen. Skripsi. Program studi Teknik Pertanian. Universitas Lampung. 79 hal.

Sambeganarko, A. 2008. Pengaruh Aplikasi $\mathrm{KMnO}_{4}$, Ethylene block, Larutan $\mathrm{CaCl}$ dan CaO Terhadap Kualitas dan Umur Simpan Pisang (Musa paradisiacal.L) Varietas Raja Bulu. Program studi Holtikultura. Fakultas Pertanian. Institut Pertanian Bogor. Bogor.

Sholihati. 2004. Kajian Penggunaan Bahan Penyerap Etilen Kalium Permanganat Untuk Memperpanjang Umur Simpan Pisang Raja (Musa paradisiacal varSapientum L) Tesis. Sekolah Pasca Sarjana IPB. Bogor.

Sunarmani, S. Elizabeth, dan S. Sentausa. 1996. Pengaruh Komposisi Oksigen dan Karbondioksida dalam Wadah Tertutup Terhadap Mutu dan Daya Simpan Nenas. J.Hort.5(5): 80-93.

Trenggono dan Sutardi. 1989. Biokimia dan Teknologi Pasca Panen. Pusat Antar Universitas Pangan dan Gizi UGM. Yogyakarta.

Usman, A. 2013. Teknologi Penanganan Pascapanen Buahan Dan Sayuran. Graha Ilmu. Yogyakarta. $141 \mathrm{hlm}$. 